\title{
Two novel mutations identified in the Wiskott-Aldrich syndrome protein gene cause Wiskott-Aldrich syndrome and thrombocytopenia
}

\author{
NURIA ANDREU ${ }^{1}$, NÚRIA MATAMOROS $^{2}$, ANTONIO ESCUDERO $^{3}$ and CRISTINA FILLAT ${ }^{1}$ \\ ${ }^{1}$ Programa Gens i Malaltia, Centre de Regulació Genòmica CRG-UPF, Parc de Recerca Biomèdica (PRBB), \\ Dr. Aiguader 88, Barcelona; ${ }^{2}$ Servei d'Immunologia, Hospital Son Dureta, Palma de Mallorca; \\ ${ }^{3}$ Unidad de Hematología, Hospital General Universitario Gregorio Marañon, Madrid, Spain
}

Received November 30, 2006; Accepted January 22, 2007

\begin{abstract}
Wiskott-Aldrich syndrome (WAS) and X-linked thrombocytopenia (XLT) are rare X-linked genetic disorders caused by mutations of the Wiskott-Aldrich syndrome protein (WASP) gene. Both disorders are clinically characterized by chronic thrombocytopenia of small platelets. WAS is a more severe form of the disorder and also courses with eczema, and immune dysfunction. In the present study, we investigated two novel mutations of the WASP gene in two Spanish families with patients clinically diagnosed as having XLT and WAS, respectively. In one of the families a missense mutation in exon $12(1488 \mathrm{~A}>\mathrm{G})$, resulting in the highly conserved glutamic residue changing to glycine at position 485 (D485G), was identified in several members. Notably, a female of this family, with clinical signs of XLT, was determined as the carrier of the mutation and showed a skewed pattern of X-inactivation, preferentially inactivating the X-chromosome carrying the wild-type allele. In the case of the second family, we describe a WAS patient with a single base deletion in exon 2 (266-267delA), resulting in a frameshift (at codon 78) that creates a stop codon at amino acid 127. As a consequence, there was no WASP expression.
\end{abstract}

\section{Introduction}

Wiskott-Aldrich syndrome (WAS) is a rare X-linked genetic disorder (MIM \#301000) characterized by the clinical triad:

Correspondence to: Dr Cristina Fillat, Centre de Regulació Genòmica, Dr. Aiguader 88, 08003 Barcelona, Spain

E-mail: cristina.fillat@crg.es

Abbreviations: WAS, Wiskott-Aldrich syndrome; WASP, Wiskott-Aldrich syndrome protein; XLT, X-linked thrombocytopenia; HUMARA, human androgen receptor

Key words: Wiskott-Aldrich syndrome, X-linked thrombocytopenia, frameshift, missense mutation, X-chromosome inactivation thrombocytopenia with small platelets, eczema, and symptoms of immune dysfunction. Classically the phenotype of affected males is severe, although heterozygous females are usually asymptomatic. However, several cases of WAS carriers with clinical signs have been reported (reviewed in ref. 1).

The WASP gene encodes a multidomain protein (WASP) that is expressed predominantly in hematopoietic lineages. The main function of WASP is to couple signals generated at the cell membrane level with the reorganization of the cellular cytoskeleton, ultimately resulting in cell activation and the promotion of cell motility (2).

The gene responsible for WAS is located on the short arm of the X-chromosome in region Xp11.23-p11.22 (3). Approximately 300 unique mutations have been reported in the WASP gene, but only five mutational hotspots have been clearly identified (4-6) (http://homepage.mac.com/ kohsukeimai/wasp/WASPbase.html). Diagnosed patients show remarkable heterogeneity of clinical symptoms, ranging from isolated thrombocytopenia (X-linked thrombocytopenia, XLT; MIM\#313900) to severe disease, including pyogenic and opportunistic infections, autoimmune disease, and malignancy, while microthrombocytopenia was found to be present in all patients $(3,7,8)$. Few WASP mutations have been identified to cause any disease other than typical WAS/XLT. Such cases include very mild missense mutations affecting the C-terminus and resulting in an intermittent form of XLT (9), and gain-offunction missense mutations that result in X-linked neutropenia, without signs of WAS/XLT $(10,11)$.

In the present study we described two novel mutations in the WASP gene: a missense mutation of D485G on exon 12 (family A) and a deletion on exon 2 (266-267delA, family B) that resulted in XLT and classical WAS, respectively.

\section{Materials and methods}

Case report. Family A: Patient I.1. (index case) is a woman originally diagnosed as having immune thrombocytopenic purpura (ITP, MIM\#188030). At the time of diagnosis her platelet count was $39,000 / \mathrm{mm}^{3}$, and following corticosteroid treatment platelet counts reached normal values. She was in good general condition, and no major infections were recorded in her clinical history. Other hematological and immunological 
Table I. Platelet values and immunological characteristics of family A.

\begin{tabular}{lccccc}
\hline Variable & \multicolumn{3}{c}{ Subject no. } & Normal range \\
\cline { 2 - 5 } & I.1. & II.1. & II.2. & II.3. \\
\hline Platelets $^{\mathrm{a}}$ & $39,000-313,000$ & $115,000-152,000$ & $187,000-192,000$ & $211,000-250,000$ & $140,000-400,000$ \\
MPV (fl) & $5.5-7.3$ & $5.7-6.1$ & $6.1-7.2$ & $7.0-8.2$ & $7.5-11.0$ \\
Serum immunoglobulins (mg/dl) & & & & 796 \\
IgG & 1090 & 882 & 699 & 475 & $723-1685$ \\
IgA & 337 & 296 & 421 & 192 & $69-382$ \\
IgM & 165 & 105 & 85 & 6 & $40-230$ \\
IgE & 1290 & 60 & $<2$ & $3-160$ \\
\hline
\end{tabular}

${ }^{\mathrm{a}}$ Number of platelets $/ \mathrm{mm}^{3}$.

parameters of subject I.1., as well as of other family members, are shown in Table I. The possibility of XLT was eventually considered. Her sons (II.1 and II.2) had X-linked thrombocytopenia with small platelets, whereas her daughter (II.3) had normal platelet values.

Family B: The propositus is a boy, clinically diagnosed with Wiskott-Aldrich syndrome. From the age of 4 months he presented thrombocytopenia with small platelets, eosinophilia and eczema. His platelet count was $38,000 / \mathrm{mm}^{3}$, with a mean platelet volume of $6.8 \mathrm{fl}$ (normal range 7.5-11 fl). His clinical history was unremarkable in terms of infection. Immunological studies indicated that lymphocyte counts and serum immunoglobulins were normal. The clinical diagnosis was molecularly confirmed with the identification of the mutation reported in the present study. An allogeneic peripheral stem cell transplant (PBSCT), from an unrelated HLA-compatible donor, was performed at the age of 16 months. The number of subpopulations of hematopoietic cells present was found to be normal, and his peripheral blood cells presented complete chimerism. Following the transplant he suffered an Epstein-Barr viral infection and responded well to ganciclovir and intravenous immunoglobulin. At present, he remains healthy. Treatment with intravenous immunoglobulin was established to minimize the risk of infection.

Screening for WASP mutation. Genomic DNA was obtained from peripheral blood leukocytes by the salting out method (12). The 12 exons and the flanking splice site of the WASP gene were amplified and analysed by single-strand conformation analysis (SSCA) (13). Direct DNA sequencing was performed on the samples that revealed a change in SSCA. For DNA sequencing, the PCR products were purified and sequenced with the BigDye terminator cycle sequencing kit (Applied Biosystems) on an ABI PRISM 3100 genetic analyser (Applied Biosystems). The mutations detected were confirmed by sequencing in the opposite direction and using two independent polymerase chain reaction (PCR) amplifications.

HUMARA assay. A semi-quantitative analysis of $\mathrm{X}$ chromosome inactivation was performed by the Human
Androgen Receptor (HUMARA) assay, as previously reported (1).

Computational methods. ClustalW (http://www.ebi.ac.uk/ clustalw) was used to align the WASP protein sequences of four mammalian species represented in the GenBank and of Xenopus laevis and Danio rerio.

\section{Results}

In family $\mathrm{A}$, sequencing analysis revealed a single base substitution of $A$ for $\mathrm{G}$ at nucleotide 1488 in exon 12 of the WASP gene $(1488 \mathrm{~A}>\mathrm{G})$. This missense mutation changes codon 485 from GAC to GGC; the amino acid glutamic changes to glycine at position 485 of the WASP protein (D485G). The mutation was detected in woman I.1. (Fig. 1), her sons (II.1. and II.2.) and daughter (II.3.), indicating that both women were carriers of the mutation. No other changes to the WASP gene were recorded.

The amino acid change $\mathrm{D} 485 \mathrm{G}$ occurred within the Verprolin Central Acidic (VCA) domain of the WASP gene, at a highly conserved residue of the WASP gene, as identified by the multiple sequence alignment of the VCA domains of WASPs of different species (Fig. 1B). The data suggest that such a modification was very likely to have produced protein changes which in turn would have led to the development of the disease. Moreover, no such nucleotide change was detected in over 100 normal $\mathrm{X}$-chromosomes studied, thus eliminating the possibility that the change could have been a polymorphism.

Notably, woman I.1. had clinical signs of thrombocytopenia, with a reduced platelet volume. Since changes in the pattern of $\mathrm{X}$-chromosome inactivation have already been reported to cause the disease in carriers of X-linked diseases, we decided to study the X-chromosome inactivation patterns of the family (Fig. 1C). The pattern was found to be different for each female family member. We observed a random pattern of inactivation in girl II.3. (57\% of cells had a WASP mutated active allele), whereas woman I.1. had a skewed pattern of X-inactivation, preferentially inactivating the $\mathrm{X}$ chromosome carrying the wild-type allele (262 bp) (85\% of 
A

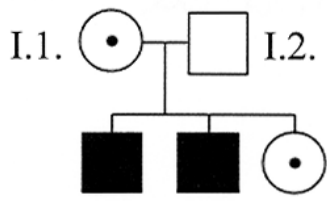

II.1. II.2. II.3.

B

HS 468 GALMHVMQKRSRAIHSSDEGEDQAG-DE 494 Cf 469 GALMHVMOKRSRAIHSSDEGEDQAG-DE 495 Mm 486 GALMHVMOKRSRVTHSSDEGEDOTG-ED 512 Rn 401 GALMHVQKRSKVIHSSDEGEDQTG-ED 427 XI 435 GALMHVMOKRSKAIHSSDDDDDEDGADD 462 Dr 445 GALMMVMQKRSKVIHSSEDEEDDGG-EE 471

$\mathrm{C}$ $\begin{array}{ccc}\text { I.1. } & \text { II.1. } \\ 262 & 280 & 280 \\ & \wedge & \Lambda\end{array}$ II.2. II.3. -HpaII ${ }^{280} \Omega^{280}$ + HpaII

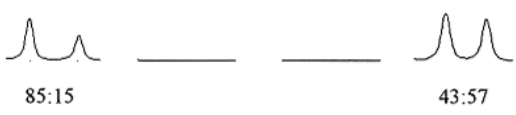

Figure 1. Family A: Pedigree and molecular analysis of the WASP gene. (A) Pedigree of family A. Filled squares indicate affected boys (II.1. and II.2.) Circles with a dot represent female carriers (I.1. and II.3.). Open square indicates non-affected male (I.2). (B) Alignment of amino acid sequences for genes orthologous to WASP: Hs, Homo sapiens; Cf, Canis familiaris; Mm, Mus musculus; Rt, Rattus norvegicus; X1, Xenopus laevis; and Dr, Danio rerio. ClustalW alignment of residues 468-494 of human WASP with dog, mouse, rat, zebra fish (Danio rerio) and Xenopus orthologs. D485 is highlighted in grey. (C) X-chromosome inactivation study. DNA samples extracted from whole blood cells were directly amplified by PCR with specific primers that flank the HUMARA gene (labelled as - HpaII), or digested with methylation-sensitive enzyme HpaII, followed by PCR amplification of the HUMARA gene (labelled + HpaII). The alleles amplified after $\mathrm{HpaII}$ digestion correspond to the inactive X-chromosome. The samples were analysed with GeneScan software. Boys (II.1 and II.2) amplified only one allele in non-digested conditions ( $280 \mathrm{bp}$ ), corresponding to the active chromosome which carries the WASP mutation. All female members were heterozygous at the HUMARA gene, with a total of three bands detected (262-, 280- and 283-bp alleles).

cells). As expected, in the case of the WAS boys (II.1. and II.2.), the X-chromosome that carried the mutation (280 bp) was active. Abnormalities in the $\mathrm{X}$-inactivation process have been associated with a point mutation in the minimal promoter of XIST (14). We performed screening for cytosine-to-guanine mutation in the XIST minimal promoter for the female members of the family, but no mutation was detected (data not shown).

In family B, sequence analysis of genomic DNA from the affected boy (III.1.) revealed the presence of one base pair deletion, 266-267delA, on exon 2 (Fig. 2). This change resulted in a frameshift (at codon 78) and created a stop codon at amino acid 127 (exon 4). No other changes were detected in the WASP gene of this patient. The same nucleotide change was detected in his mother (II.1.) in heterozygosis, indicating that she was a carrier of the mutation. In contrast, his grandmother (I.1.) was not a carrier (Fig. 2), indicating that the mutation originated de novo in the mother (II.1). We also analysed the expression of the WASP gene in RNA samples from the affected boy (III.1.), using RT-PCR, and no abnormal products were detected (data not shown). However, Western blot analysis showed no expression of the WASP
A

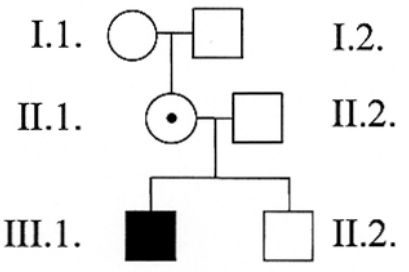

B

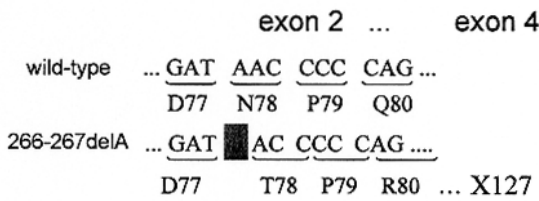

Figure 2. Family B: Pedigree and molecular analysis of the WASP gene. (A) Pedigree of family B. The filled square indicates the WAS patient (III.1.). The circle with a dot represents the asymptomatic female carrier (II.1.). The circle represents the healthy female (I.1.). Open squares indicate the nonaffected males (I.2, II.2 and III.2). (B) Explanation of the frameshift mutation.

gene, thus suggesting that the truncated protein was unstable (data not shown).

\section{Discussion}

The majority of mutations identified in the WASP gene pertain to the group of missense mutations, and mostly localise in the four first exons. The second most common type of WASP mutations are splice site mutations and occur predominantly in the downstream part (introns 6-11) of the WASP gene. Along the whole gene, but with reduced frequency, deletions, insertions, nonsense and complex mutations are also to be found (4-6).

Interestingly, for the first time, in the present paper we describe a family with a missense mutation in exon 12 of the WASP gene, that has been associated with XLT. Until now only 6 different mutations have been reported on exon 12 (Table II): two missense mutations in the last codon of the WASP protein (X503R and X503S) $(5,15)$, two deletions (1519delT and 1543delAGTG) (16,17), a splice defect (4) and a complex mutation (18). All these mutations resulted in aberrant WASP protein or an absence of WASP expression, and have been associated with a severe WAS phenotype. The reduced number of mutations identified in the exon could be partially accounted for by the fact that nucleotide changes resulting in amino acid substitutions in these region might coincide with a very mild phenotype, thus escaping a diagnose of WAS or XLT. In fact it is well documented that $\mathrm{X}$-linked thrombocytopenia (XLT) is sometimes misdiagnosed as chronic idiopathic thrombocytopenic purpura (ITP) $(19,20)$.

The molecular basis of the described mutation is unknown. Interestingly, in the WASP protein, preceding amino acid 485 , there are two serine residues, S483 and S484. Their phosphorylation has been reported to be required for efficient in vitro actin polymerization by WASP (21). One could speculate that the nucleotide substitution (D485G) may introduce a conformational change that affects serine phosphorylation resulting in a less functional protein. 
Table II. Summary of published WASP mutations found in exons 2 and 12.

\begin{tabular}{|c|c|c|c|c|c|c|}
\hline Exon & Mutation & Effect & Type & Reference & Protein & Protein $^{\mathrm{d}}$ \\
\hline $2^{\mathrm{a}}$ & $168 \mathrm{C}>\mathrm{T}$ & $\mathrm{T} 45 \mathrm{M}$ & Missense & (26) & N.D. & $\mathrm{R}$ or - \\
\hline 2 & $171 \mathrm{~T}>\mathrm{C}$ & $\mathrm{L} 46 \mathrm{P}$ & Missense & (27) & N.D. & \\
\hline 2 & $174 C>A$ & A47D & Missense & $(7)$ & N.D. & $\mathrm{R}$ \\
\hline 2 & $177 \mathrm{C}>\mathrm{T}$ & $\mathrm{T} 48 \mathrm{I}$ & Missense & (28) & N.D. & $\mathrm{R}$ \\
\hline 2 & $185 \mathrm{G}>\mathrm{T}$ & V51F & Missense & (6) & - & \\
\hline 2 & $190 \mathrm{G}>\mathrm{C}$ & Q52H & Missense & (29) & N.D. & \\
\hline 2 & $201 \mathrm{C}>\mathrm{T}$ & A56V & Missense & (30) & N.D. & $\mathrm{R}$ \\
\hline 2 & $201 \mathrm{C}>\mathrm{G}$ & A56V & Missense & (31) & N.D. & \\
\hline 2 & $206 \mathrm{C}>\mathrm{G}$ & P58A & Missense & (5) & $\mathrm{R}$ & $\mathrm{R}^{\mathrm{e}}$ \\
\hline 2 & $207 \mathrm{C}>\mathrm{T}$ & P58L & Missense & (26) & N.D. & \\
\hline 2 & $207 \mathrm{C}>\mathrm{G}$ & P58R & Missense & (9) & + & + \\
\hline 2 & $224 \mathrm{~T}>\mathrm{C}$ & W64R & Missense & (32) & N.D. & \\
\hline 2 & $242 \mathrm{G}>\mathrm{T}$ & G70W & Missense & (29) & N.D. & \\
\hline 2 & $251 \mathrm{~T}>\mathrm{C}$ & C73R & Missense & (33) & - & \\
\hline 2 & $252 \mathrm{G}>\mathrm{A}$ & C73Y & Missense & (34) & $\mathrm{R}$ & $\mathrm{R}$ \\
\hline 2 & $255 \mathrm{~T}>\mathrm{C}$ & F74S & Missense & (5) & N.D. & \\
\hline 2 & $257 \mathrm{G}>\mathrm{A}$ & V75M & Missense & (16) & N.D. & $\mathrm{R}$ or + \\
\hline 2 & $261 \mathrm{~A}>\mathrm{C}$ & K76T & Missense & (5) & N.D. & \\
\hline 2 & $263 \mathrm{G}>\mathrm{C}$ & D77H & Missense & (5) & $\mathrm{R}$ & \\
\hline 2 & $264 \mathrm{~A}>\mathrm{G}$ & D77G & Missense & (35) & $\mathrm{R}$ & $\mathrm{R}$ \\
\hline 2 & $278 \mathrm{~T}>\mathrm{C}$ & $\mathrm{S} 82 \mathrm{P}$ & Missense & (16) & N.D. & $\mathrm{R}$ \\
\hline 2 & $279 \mathrm{C}>\mathrm{T}$ & $\mathrm{S} 82 \mathrm{~F}$ & Missense & (36) & N.D. & \\
\hline 2 & $282 \mathrm{~A}>\mathrm{G}$ & Y83C & Missense & (33) & + & \\
\hline 2 & $284 \mathrm{~T}>\mathrm{C}$ & F84L & Missense & (37) & - & $-f$ \\
\hline 2 & $288 \mathrm{~T}>\mathrm{C}$ & I85T & Missense & (38) & N.D. & \\
\hline $2^{\mathrm{a}}$ & $290 \mathrm{C}>\mathrm{A}$ & R86S & Missense & (39) & N.D. & N.D. \\
\hline $2^{\mathrm{a}}$ & $290 \mathrm{C}>\mathrm{G}$ & R86G & Missense & (5) & $\mathrm{R}$ & \\
\hline $2^{\mathrm{a}}$ & $290 \mathrm{C}>\mathrm{T}$ & $\mathrm{R} 86 \mathrm{C}$ & Missense & (16) & N.D. & R or - \\
\hline $2^{\mathrm{a}}$ & $291 \mathrm{G}>\mathrm{A}$ & $\mathrm{R} 86 \mathrm{H}$ & Missense & (3) & N.D. & R or - \\
\hline $2^{\mathrm{a}}$ & $291 \mathrm{G}>\mathrm{T}$ & R86L & Missense & (28) & N.D. & - \\
\hline $2^{\mathrm{a}}$ & $291 \mathrm{G}>\mathrm{C}$ & $\mathrm{R} 86 \mathrm{P}$ & Missense & (27) & N.D. & \\
\hline 2 & $300 \mathrm{G}>\mathrm{A}$ & G89D & Missense & (37) & + & \\
\hline 2 & $196 \mathrm{C}>\mathrm{A}$ & Y54X & Nonsense & (40) & N.D. & $-g$ \\
\hline 2 & $272 \mathrm{C}>\mathrm{T}$ & Q80X & Nonsense & (16) & N.D. & \\
\hline 2 & $283 C>A$ & Y83X & Nonsense & (41) & - & \\
\hline 2 & $298 \mathrm{C}>\mathrm{A}$ & Y88X & Nonsense & (42) & - & \\
\hline 2 & 186-196del & $51 \mathrm{fs} / 58 \mathrm{X}$ & Deletion & (5) & - & \\
\hline 2 & 201-213del & $56 \mathrm{fs} / 71 \mathrm{X}$ & Deletion & (5) & N.D. & \\
\hline 2 & 206-210delC & $59 \mathrm{fs} / 75 \mathrm{X}$ & Deletion & (43) & N.D. & N.D. \\
\hline 2 & 211delT & $59 \mathrm{fs} / 75 \mathrm{X}$ & Deletion & (3) & N.D. & - \\
\hline 2 & 211delT & $59 \mathrm{fs} / 75 \mathrm{X}$ & Complex & (5) & N.D. & \\
\hline 2 & $211 \mathrm{~T}>\mathrm{C}$ & P59P & (2 Mutations) & & & \\
\hline 2 & 237-246del & $68 \mathrm{fs} / 72 \mathrm{X}$ & Deletion & (5) & - & \\
\hline 2 & 248delG & $72 \mathrm{fs} / 75 \mathrm{X}$ & Deletion & (36) & N.D. & \\
\hline 2 & 260-261delA & $76 f s / 126 X$ & Deletion & (4) & - & \\
\hline 2 & 268delC & $77 \mathrm{fs} / 127 \mathrm{X}$ & Deletion & (16) & N.D. & \\
\hline 2 & 279-280delC & $82 \mathrm{fs} / 126 \mathrm{X}$ & Deletion & (5) & N.D. & \\
\hline 2 & 283delCTTCA & $84 \mathrm{fs} / 119 \mathrm{X}$ & Deletion & (4) & - & \\
\hline 2 & 218-219insG & $62 \mathrm{fs} / 78 \mathrm{X}$ & Insertion & (44) & N.D. & \\
\hline $12^{\mathrm{b}}$ & $1507 \mathrm{~T}>\mathrm{A}$ & X503R, 581 aa protein & Missense & (15) & - & \\
\hline 12 & 1519delT & Fs/extend polyA & Deletion & (17) & - & \\
\hline 12 & $1542 \mathrm{G}>\mathrm{C}$ & X503S & Missense & (5) & - & \\
\hline 12 & 1543delAGTG & Extend polyA & Deletion & (16) & N.D. & \\
\hline 12 & No mutation in coding region & Normal and abnormal cDNA & Ins intron 11 (118 bp) & (4) & + & \\
\hline $12^{c}$ & Complex mutation & 519 aa protein & Inversion/deletion & (18) & + & \\
\hline
\end{tabular}

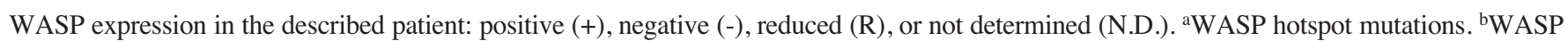
mutation described in the original article as $1507 \mathrm{~T}>\mathrm{A}$, however the $\mathrm{T}$ nucleotide in codon 503 corresponds to position $1541 .{ }^{\mathrm{c}} \mathrm{Complex}$ mutation: at the genomic level the mutation involves a small 9-bp deletion, followed by a 151-bp inversion and a large deletion of $4.3 \mathrm{~kb}$, involving intron 11, exon 12 and the $3^{\prime}$ UTR of the WASP gene, and the genomic region upstream of the contiguous SUV39H1 gene. ${ }^{\mathrm{d}} \mathrm{WASP}$ protein expression in new patients not included in the first report. The data was obtained from http://homepage.mac.com/kohsukeimai/ wasp/WASPbase.html or from references ${ }^{\mathrm{e}}(6),{ }^{\mathrm{f}}(45)$, and ${ }^{\mathrm{g}}(46)$. 
Female carriers of $\mathrm{X}$-linked disorders are, in most cases, asymptomatic. This is explained by a skewed $\mathrm{X}$-inactivation pattern with preferential selection of the normal, non-mutated $\mathrm{X}$-chromosome as the active allele in the target cells. This could result from somatic selection after X-inactivation, leading to the survival of the lineages bearing the wild-type allele. In WAS carriers a defect in the migration of WASPdeficient hematopoietic stem cells has been proposed as the cause of such skewed X-inactivation (22). However, several reports of females with clinical signs of WAS have been described many of whom were associated with alterations in the X-inactivation pattern (reviewed in ref. 1).

In family A we described a new female case of XLT with clinical signs. She presented a skewed pattern of the Xchromosome inactivation, but with preferential activation of the mutated allele. Her daughter, completely free of XLT symptoms, was also heterozygous for the WASP mutation, but presented a random pattern of X-chromosome inactivation. Females with clinical signs of WAS and a random pattern of $\mathrm{X}$-inactivation have also been described, although in all cases the causative mutation presented a strong WAS phenotype in the male offspring of the family, thus suggesting a major impact of the mutations in WASP protein alteration (23-25). The data appear to indicate that in XLT mutations an aberrant strong skewed $\mathrm{X}$-inactivation pattern is required to develop clinical symptoms in female carriers.

In family B, a novel mutation 266-267delA in the WASP gene was identified and associated with the absence of WASP protein (data not shown), presumably because of the resulting frameshift and the formation of a truncated protein. Exon 2 is one of the exons in which more mutations, 50, have been identified (Table II). Moreover, two of the five hotspots described so far are located in exon 2 . The most common mutations in the region are missense followed by small deletions. As with the case described in this study, these deletions have been associated with a severe phenotype and, in patients whose protein expression has been studied, a lack of protein was also reported.

To summarise, we described two novel mutations in the WASP gene. A missense mutation in exon 12 associated with XLT, and a frameshift mutation in exon 2 associated with classical WAS. Importantly, a new case of a female with clinical signs of WAS were described in association with XLT.

\section{Acknowledgements}

Our research was supported by Fundació La Marató de TV3 (grant no. 99/3510), by Generalitat de Catalunya SGR05 00008 and by CIBER CB06/07/0089. N.A. was supported by a contract from the Fondo de Investigación Sanitaria. We also wish to give our thanks to the Servei de Genòmica of the Universitat Pompeu Fabra.

\section{References}

1. Andreu N, Pujol-Moix N, Martinez-Lostao L, et al: WiskottAldrich syndrome in a female with skewed X-chromosome inactivation. Blood Cells Mol Dis 31: 332-337, 2003.

2. Notarangelo LD and Ochs HD: WASP and the phenotypic range associated with deficiency. Curr Opin Allergy Clin Immunol 5: 485-490, 2005.
3. Derry JM, Ochs HD and Francke U: Isolation of a novel gene mutated in Wiskott-Aldrich syndrome. Cell 78: 635-644, 1994.

4. Imai K, Morio T, Zhu Y, et al: Clinical course of patients with WASP gene mutations. Blood 103: 456-464, 2004.

5. Jin Y, Mazza C, Christie JR, et al: Mutations of the WiskottAldrich Syndrome Protein (WASP): hotspots, effect on transcription, and translation and phenotype/genotype correlation. Blood 104: 4010-4019, 2004.

6. Lutskiy MI, Rosen FS and Remold-O'Donnell E: Genotypeproteotype linkage in the Wiskott-Aldrich syndrome. J Immunol 175: 1329-1336, 2005.

7. Zhu Q, Zhang M, Blaese RM, et al: The Wiskott-Aldrich syndrome and X-linked congenital thrombocytopenia are caused by mutations of the same gene. Blood 86: 3797-3804, 1995.

8. Ochs HD and Rosen FS: The Wiskott-Aldrich Syndrome. In: Primary Immunodeficiency Diseases: A Molecular and Genetic Approach. Ochs HD and Puck JM (eds). Oxford University Press, Inc., Oxford, pp292-305, 1999.

9. Notarangelo LD, Mazza C, Giliani S, et al: Missense mutations of the WASP gene cause intermittent X-linked thrombocytopenia. Blood 99: 2268-2269, 2002.

10. Devriendt K, Kim AS, Mathijs G, et al: Constitutively activating mutation in WASP causes X-linked severe congenital neutropenia. Nat Genet 27: 313-317, 2001.

11. Ancliff PJ, Blundell MP, Cory GO, et al: Two novel activating mutations in the Wiskott-Aldrich syndrome protein result in congenital neutropenia. Blood 108: 2182-2189, 2006.

12. Miller SA, Dykes DD and Polesky HF: A simple salting out procedure for extracting DNA from human nucleated cells. Nucleic Acids Res 16: 1215, 1988

13. Fillat C, Espanol T, Oset M, Ferrando M, Estivill X and Volpini V: Identification of WASP mutations in 14 Spanish families with Wiskott-Aldrich syndrome. Am J Med Genet 100: 116-121, 2001

14. Plenge RM, Hendrich BD, Schwartz C, et al: A promoter mutation in the XIST gene in two unrelated families with skewed X-chromosome inactivation. Nat Genet 17: 353-356, 1997.

15. Chatchatee P, Srichomthong C, Chewatavorn A and Shotelersuk V: A novel termination codon mutation of the WAS gene in a Thai family with Wiskott-Aldrich syndrome. Int J Mol Med 12: 939-941, 2003.

16. Kolluri R, Shehabeldin A, Peacocke M, et al: Identification of WASP mutations in patients with Wiskott-Aldrich syndrome and isolated thrombocytopenia reveals allelic heterogeneity at the WAS locus. Hum Mol Genet 4: 1119-1126, 1995

17. Shcherbina A, Rosen FS and Remold-O'Donnell E: WASP levels in platelets and lymphocytes of Wiskott-Aldrich syndrome patients correlate with cell dysfunction. J Immunol 163: 6314-6320, 1999.

18. Andreu N, Garcia-Rodriguez M, Volpini V, et al: A novel Wiskott-Aldrich syndrome protein (WASP) complex mutation identified in a WAS patient results in an aberrant product at the C-terminus from two transcripts with unusual polyA signals. J Hum Genet 51: 92-97, 2006.

19. Kanegane H, Nomura K, Miyawaki T, et al: X-linked thrombocytopenia identified by flow cytometric demonstration of defective Wiskott-Aldrich syndrome protein in lymphocytes. Blood 95: 1110-1111, 2000.

20. Proust A, Guillet B, Pellier I, et al: Recurrent V75M mutation within the Wiskott-Aldrich syndrome protein: description of a homozygous female patient. Eur J Haematol 75: 54-59, 2005.

21. Cory GO, Cramer R, Blanchoin L and Ridley AJ: Phosphorylation of the WASP-VCA domain increases its affinity for the Arp $2 / 3$ complex and enhances actin polymerization by WASP. Mol Cell 11: 1229-1239, 2003.

22. Lacout C, Haddad E, Sabri S, et al: A defect in hematopoietic stem cell migration explains the nonrandom X-chromosome inactivation in carriers of Wiskott-Aldrich syndrome. Blood 102: 1282-1289, 2003.

23. de Saint Basile G, Lagelouse RD, Lambert N, et al: Isolated Xlinked thrombocytopenia in two unrelated families is associated with point mutations in the Wiskott-Aldrich syndrome protein gene. J Pediatr 129: 56-62, 1996.

24. Lutskiy MI, Sasahara Y, Kenney DM, Rosen FS and Remold-O'Donnell E: Wiskott-Aldrich syndrome in a female. Blood 100: 2763-2768, 2002.

25. Inoue $\mathrm{H}$, Kurosawa $\mathrm{H}$, Nonoyama $\mathrm{S}$, et al: X-linked thrombocytopenia in a girl. Br J Haematol 118: 1163-1165, 2002. 
26. Kwan SP, Hagemann TL, Radtke BE, Blaese RM and Rosen FS: Identification of mutations in the Wiskott-Aldrich syndrome gene and characterization of a polymorphic dinucleotide repeat at DXS6940, adjacent to the disease gene. Proc Natl Acad Sci USA 92: 4706-4710, 1995.

27. Schindelhauer D, Weiss M, Hellebrand H, et al: WiskottAldrich syndrome: no strict genotype-phenotype correlations but clustering of missense mutations in the amino-terminal part of the WASP gene product. Hum Genet 98: 68-76, 1996.

28. Derry JM, Kerns JA, Weinberg KI, et al: WASP gene mutations in Wiskott-Aldrich syndrome and X-linked thrombocytopenia. Hum Mol Genet 4: 1127-1135, 1995.

29. El-Hakeh J, Rosenzweig S, Oleastro M, et al: Wiskott-Aldrich syndrome in Argentina: 17 unique, including nine novel, mutations. Hum Mutat 19: 186-187, 2002.

30. Villa A, Notarangelo L, Macchi P, et al: X-linked thrombocytopenia and Wiskott-Aldrich syndrome are allelic diseases with mutations in the WASP gene. Nat Genet 9: 414-417, 1995.

31. Wengler GS, Notarangelo LD, Berardelli S, et al: High prevalence of nonsense, frame shift, and splice-site mutations in 16 patients with full-blown Wiskott-Aldrich syndrome. Blood 86: 3648-3654, 1995

32. Fillat C, Espanol T, Oset M, et al: Two novel mutations in the WASP gene in Wiskott-Aldrich patients of Chile origin: W64R and A124E. Hum Mutat 15: 487, 2000

33. Lemahieu V, Gastier JM and Francke U: Novel mutations in the Wiskott-Aldrich syndrome protein gene and their effects on transcriptional, translational, and clinical phenotypes. Hum Mutat 14: 54-66, 1999.

34. Loutski M, Remold-O'Donnell E, Roumiantsev AG and Shcherbina A: Phenotype-genotype correlation and mutation identification in patients with the Wiskott-Aldrich syndrome. Russ J Immunol 6: 257-264, 2001.

35. Allavena P, Badolato R, Facchetti F, et al: Monocytes from Wiskott-Aldrich patients differentiate in functional mature dendritic cells with a defect in CD83 expression. Eur J Immunol 31: 3413-3421, 2001.
36. Kwan SP, Hagemann TL, Blaese RM, Knutsen A and Rosen FS Scanning of the Wiskott-Aldrich syndrome (WAS) gene: identification of 18 novel alterations including a possible mutation hotspot at Arg86 resulting in thrombocytopenia, a mild WAS phenotype. Hum Mol Genet 4: 1995-1998, 1995.

37. MacCarthy-Morrogh L, Gaspar HB, Wang YC, et al: Absence of expression of the Wiskott-Aldrich syndrome protein in peripheral blood cells of Wiskott-Aldrich syndrome patients. Clin Immunol Immunopathol 88: 22-27, 1998.

38. Ariga T, Kondoh T, Yamaguchi K, et al: Spontaneous in vivo reversion of an inherited mutation in the Wiskott-Aldrich syndrome. J Immunol 166: 5245-5249, 2001.

39. Bourne HC, Weston S, Prasad M, Edkins E and Benson EM: Identification of WASP mutations in 10 Australian families with Wiskott-Aldrich syndrome and X-linked thrombocytopenia. Pathology 36: 262-264, 2004

40. Brooimans RA, van den Berg AJ, Tamminga RY, Revesz T, Wulffraat NM and Zegers BJ: Identification of six novel WASP gene mutations in patients suffering from Wiskott-Aldrich syndrome. Hum Mutat 15: 386-387, 2000.

41. Ariga T, Nakajima M, Yoshida J, et al: Confirming or excluding the diagnosis of Wiskott-Aldrich syndrome in children with thrombocytopenia of an unknown etiology. J Pediatr Hematol Oncol 26: 435-440, 2004.

42. Remold-O'Donnell E Cooley J, Shcherbina A et al: Variable expression of WASP in B cell lines of Wiskott-Aldrich syndrome patients. J Immunol 158: 4021-4025, 1997.

43. Zhu Q, Watanabe C, Liu T, et al: Wiskott-Aldrich syndrome/Xlinked thrombocytopenia: WASP gene mutations, protein expression, and phenotype. Blood 90: 2680-2689, 1997.

44. Thompson LJ, Lalloz MR and Layton DM: Unique and recurrent WAS gene mutations in Wiskott-Aldrich syndrome and X-linked thrombocytopenia. Blood Cells Mol Dis 25: 218-226, 1999.

45. Qasim W, Gilmour KC, Heath S, et al: Protein assays for diagnosis of Wiskott-Aldrich syndrome and X-linked thrombocytopenia. Br J Haematol 113: 861-865, 2001.

46. Itoh S, Nonoyama S, Morio T, et al: Mutations of the WASP gene in 10 Japanese patients with Wiskott-Aldrich syndrome and X-linked thrombocytopenia. Int J Hematol 71: 79-83, 2000. 